Preprints of the

Max Planck Institute for

Research on Collective Goods

Bonn 2010/27

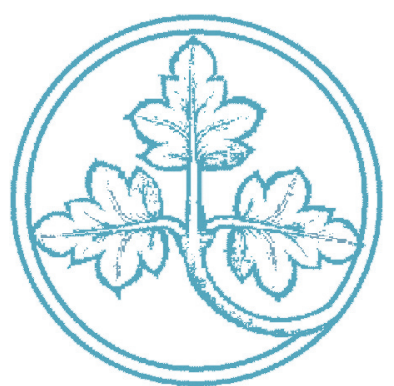

At the Mercy of the

Prisoner Next Door

Using an Experimental Measure of

Selfishness as a Criminological Tool

Thorsten Chmura

Christoph Engel

Markus Englerth

Thomas Pitz

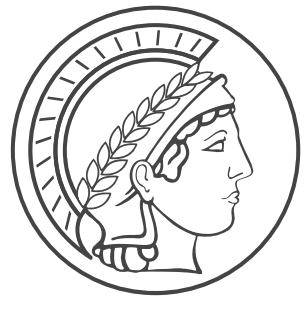




\section{At the Mercy of the Prisoner Next Door Using an Experimental Measure of Selfishness as a Criminological Tool*}

Thorsten Chmura / Christoph Engel / Markus Englerth / Thomas Pitz

June 2010 


\title{
At the Mercy of the Prisoner Next Door Using an Experimental Measure of Selfishness as a Criminological Tool ${ }^{*}$
}

\section{Thorsten Chmura / Christoph Engel / Markus Englerth / Thomas Pitz}

\begin{abstract}
Do criminals maximise money? Are criminals more or less selfish than the average subject? Can prisons apply measures that reduce the degree of selfishness of their inmates? Using a tried and tested tool from experimental economics, we cast new light on these old criminological questions. In a standard dictator game, prisoners give a substantial amount, which calls for more refined versions of utility in rational choice theories of crime. Prisoners do not give less than average subjects, not even than subjects from other closely knit communities. This speaks against the idea that people commit crimes because they are excessively selfish. Finally those who receive better marks at prison school give more, as do those who improve their marks over time. This suggests that this correctional intervention also reduces selfishness.
\end{abstract}

JEL: C34, C91, K14, K42

Keywords: Crime, Prison, Dictator Game, Experiment, Hurdle Model

Helpful comments by Daniel Nagin, Andreas Glöckner, Andreas Nicklisch, and seminar audiences at the University of Frankfurt and the PhDNet of the Max Planck Society are greatfully acknowledged. 


\section{Introduction}

Rational Choice Theory sees all people - the kindergardener no less than the entrepreneur - as self-interested, rational utility maximizers. The criminal is no exception to this rule. Since Gary S. Becker's seminal paper (Becker 1968), a flourishing literature interprets crime as optimisation under constraints (for a survey see Eide, Rubin et al. 2006). Most behavioural economists do not disagree with the individualistic starting point. Yet they draw a more nuanced picture of motivation. They in particular depart from the money maximisation assumption of economic textbooks. The dictator game is a workhorse of this literature (Kahneman, Knetsch et al. 1986; Forsythe, Horowitz et al. 1994).

Dictator games have been used to establish two findings: on average there is a substantial degree of altruism (Engel 2010); people differ in the degree of altruism, both across individuals and across cultures (Gurven 2004; Henrich and Boyd 2004; Henrich and Boyd 2005; Holm and Danielson 2005; Gurven, Zanolini et al. 2008; Barr, Wallace et al. 2009). Dictator games have been used in widely different contexts to measure heterogeneity. They have for instance proven instrumental to assess discrimination between Israelis and Palestinians (Fershtman and Gneezy 2001) or between white and black South Africans (van der Merwe and Burns 2008), and to compare social capabilities of patients suffering from Alzheimer's disease with those of healthy elderly persons (Bosch-Domènech, Nagel et al. 2010), of those suffering from sleep deprivation to unaffected controls (Anderson and Dickinson 2010), as well as of children of different age and sex (Harbaugh and Krause 2000; Harbaugh, Krause et al. 2003; Takezawa, Gummerum et al. 2006; Benenson, Pascoe et al. 2007; Houser and Schunk 2009).

The aim of our paper is to build a bridge between this strand of behavioural economics and the study of crime. More specifically we ask: (1) Do criminals maximise money? (2) Are criminals more or less selfish than the average subject? (3) Can prisons apply measures that reduce the degree of selfishness of their inmates?

The dictator game is uniquely equipped to study these questions. In the dictator game, one randomly selected participant (the "dictator") is free to distribute an assigned amount of money between himself and an anonymous recipient. He may keep everything for himself. But he may also share some or all of his endowment with the second participant who is at his mercy. The game has been interpreted as a measure of selfishness (see e.g. Bardsley 2008:122), generosity (Kahneman, Knetsch et al. 1986:S286), sociality (Kahneman, Knetsch et al. 1986:S286 "social conscience") and, of course, altruism (e.g. Andreoni and Miller 2002).

In this study, we have inmates of the German prison at Adelsheim play the dictator game. Our participants on average donate quite a bit. Relying on a meta-study of dictator games one of us has undertaken (Engel 2010), we demonstrate that our participants are at least as generous as the average citizen. Depending on the comparison group, prisoners are even more altruistic.

The prison gave us access to information about each prisoner. We know the crime, the duration of the sentence and how many months he has already served. Most interestingly, in this prison 
inmates have a chance to receive schooling. We know who was elected and which mark he received for his assiduity, engagement and performance in class on every single day. Such information is not routinely kept, not even in juvenile prisons. The chance to use this data motivated our choice of prison. It turns out that neither socio-demographic factors nor the severity of the sanction have explanatory power. By contrast, those who receive better marks at prison school are more sociable. Using information about the development of marks over time, we can show that this is a learning, not a selection effect.

Criminology is defined by an issue, not by a method. Criminology therefore has always been open to a plurality of theoretical approaches and empirical methods, and to innovation. For decades, experiments have been a tool in the criminological tool box (for summaries see Farrington 2003; Nagin and Pogarsky 2003; Petrosino, Turpin-Petrosino et al. 2003; Farrington and Welsh 2005; Farrington and Welsh 2006; Petrosino, Kiff et al. 2006). To the best of our knowledge, however, the rich body of experimental paradigms and results in a neighboring field is untapped: experimental economics (for summaries see Kagel and Roth 1995; Camerer 2003; Plott and Smith 2008; for a theoretical contribution, see Van Winden and Ash 2010).

The remainder of the paper is organized as follows. Section 2 presents the design of the experiment. Section 3 uses the result as evidence on those rational choice theories explaining crime with money maximization. Section 4 compares the degree of altruism in prisoners with altruism in different populations, and uses this as evidence on personality theories of crime. Section 5 studies the effect of criminal sanctions, and of prison schooling in particular, on generosity. Section 6 concludes.

\section{Experimental Design}

On three subsequent days in October 2009, 58 male inmates of the Adelsheim prison participated in a computerized, one shot dictator game. The experiment was computerized, using the software zTree (Fischbacher 2007). We asked each prisoner to decide how much of $5 €$ (at the exchange rate of the first experimental day: $7.34 \$$ ) to give to an anonymous inmate of the same prison. To generate a data point from each participant, we had participants decide before the computer randomly matched them to another participant, and before the computer assigned roles. For our prisoners, $5 €$ is a sizeable amount of money. On average, per month, they approximately dispose of $180 €$. Average earnings of all participants were $2.50 €$ by design.

In the experimental literature on dictator games, following (Hoffman, McCabe et al. 1994; Hoffman, McCabe et al. 1996) experimenters often guarantee dictator-experimenter anonymity through a "double blind" protocol. In keeping with this tradition, we assigned each participant an identification number. The prison administration matched identification numbers with demographic information on the respective participant, while we never learned his name. Participants were aware of this safeguard. 
We asked participants whether they agreed that the prison administration would give us information about their age, nationality, place of birth, crime for which they have been convicted, sentence, time served in prison, and marks from the prison school. We assured them that we would never learn their identity, and that we would publish aggregate results only. All agreed to give us their data.

The Adelsheim prison was built in 1974 to house juvenile delinquents. Newly arrived prisoners are tested to decide whether they are eligible for schooling. In principle, they have a legal right to this. If prisoners do not go to school, this is mainly due to the fact that they are on apprenticeship. In 2008, the prison had 765 inmates. Those who left the prison in 2008 had on average served 11 months. $24 \%$ had served less than 6 months. Less than $4 \%$ had served more than 24 months. For those who receive schooling, prison income is contingent on marks at school. ${ }^{1}$

\section{Qualifying the Rational Choice Theory of Crime}

In his seminal article on crime, Gary S. Becker posits: "A person commits an offense if the expected utility to him exceeds the utility he could get by using his time and other resources at other activities" (Becker 1968:176). Becker is relatively vague about the definition of "utility" (cf. Becker 1968:177). But it is safe to assume that he only considered selfish motives. He did certainly not have in mind what later modellers have called inequity aversion (Fehr and Schmidt 1999; Bolton and Ockenfels 2000; Engelmann and Strobel 2004; Barr, Wallace et al. 2009), altruism (Andreoni and Miller 2002), social welfare orientation (Charness and Rabin 2002), or the psychological benefit of a "warm glow" (Andreoni 1990; Andreoni 1995). According to Becker, people commit crimes since, in expected values, this serves their selfish interests best.

Prisoners are a subsample of convicted criminals. If selfishness (in the sense of money maximization) is the driving force of criminal behaviour, prisoners should be selfish. Actually, the dictator game should be a situation that is much more conducive to selfishness than the situations that led to the crimes for which these prisoners have been convicted. The game provides complete anonymity. This not only rules out legal, but also social sanctions. Roles are randomly assigned. A dictator may therefore assuage bad conscience by the claim that the recipient might as well have been lucky enough to be dictator, and that the assignment of roles provides a justification for selfishness.

Against this backdrop, our main finding is surprising, Figure 1. Only 20 of our 58 participants, or $34.48 \%$ of them, kept the entire amount (which we expressed in 10 experimental currency units, worth $.50 €$ each). The remaining 38, i.e. $65.52 \%$, gave a positive amount. 12 of them, or 20.69 $\%$ of them, gave even more than half of the pie. Even in the perfectly secure lab situation, almost two thirds of our prison participants behaved in a way that cannot be explained in terms of self- 
ishness. ${ }^{2}$ Mere selfishness is not enough to explain behaviour, not even in prisoners. This does not imply that the rational choice theory of crime has to be refuted. Yet, much as experimental economics has forced researchers to refine assumptions in other domains of life, the rational choice theory of crime also would be well advised to integrate non-standard components into the utility functions of their agents.

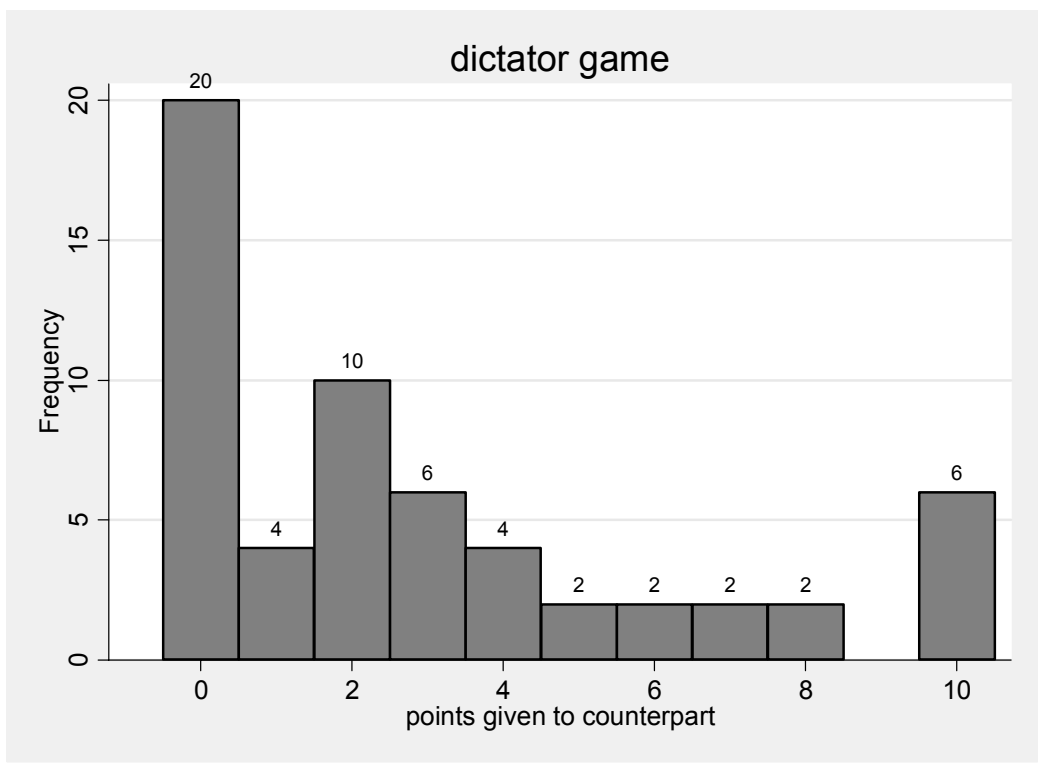

Figure 1

Dictator Game Giving

\section{Comparing Altruism in Prisoners with Altruism in Society at Large}

The fact that prisoners are not purely selfish is interesting from a theory perspective. From a policy perspective, it is more interesting whether prisoners are more selfish than the ordinary citizen. This would suggest that disproportionate selfishness contributes to committing crime (or to being convicted). To make this proposition testable, one of us has undertaken a meta-study of all 129 papers publishing dictator games, including working papers, between the beginning of the literature in 1986 and the end of 2009. From these 616 treatments, 445 do not only offer means, but standard deviations, so that meta-regression can be performed. For 328 treatments, using reported distributions of results, the original data can be reconstructed, generating a dataset of 20,817 observations (for sample composition and methodology see Engel 2010). For the purposes of comparing across populations, we merge the prison data with this dataset.

2 We cannot test the nul hypothesis that mean giving is 0 (e.g. by a one sample signrank test), since 0 is the lower bound of the support. Consequently a single positive observation suffices to reject the nul. 
If we compare prisoners with all data, they come very close. On average all participants of all 616 treatments contribute $28.35 \%$ of their endowment. ${ }^{3}$ Our prison subjects on average contribute $29.31 \%$. The difference is so small that one would not expect it to be significant. We nonetheless explain our analytic strategy at this point since we will frequently need it in this paper. That way we can also show that, using the most powerful statistical tools available, prisoners do not behave differently. The statistical challenge results from the fact that a substantial fraction of participants freeride. Therefore the data is left censored, which makes ordinary least squares inappropriate.

We use two complementary methods to tackle the problem. The first is a Tobit model. It assumes that prisoners who have given nothing might even have wanted to take money from their counterpart, had we not prevented them from this by the design of our experiment. We are in the fortunate position that this assumption has been shown empirically to be well founded. If student dictators are given a chance to take money, rather than give some, quite a few indeed do so (List 2007; Bardsley 2008).

The alternative analytic strategy assumes that the decision to give nothing is separate from the decision how much to give, conditional on the willingness to give a positive amount. This assumption is not implausible either. It has been shown that freeriders are, even at the neurological level, different from players who consider the effect of their choices on the well-being of other players. Such players do not exhibit the neural correlates of empathy. ${ }^{4}$ The appropriate statistical model for two separate processes is a hurdle model. For the decision to contribute at all, we estimate a logit model. The decision how much to contribute, conditional on the contribution being positive, is zero truncated. We have to correct the assumption on the distribution of the error term for this. If we do, the two components of the log likelihood function are additively separable, which is why we can estimate both components independently (for conceptual background see Cragg 1971; for estimation see McDowell 2003).

If we compare prisoners with all non-prisoners, neither way do we establish a significant difference, despite the fact that we have a huge dataset. The pseudo $\mathrm{R}^{2}$ shows that these models explain not the smallest bit of the variance. We may therefore safely conclude that prisoners are not more selfish than the ordinary citizen.

3 If we run a meta-regression on those 445 treatments with information on standard deviations, we get almost the same result, $28.3 \%$. The mean of the reconstructed 20,813 datapoints is 27.24 . For technical detail of these alternative measures see (Engel 2010).

4 For an overview of the neurological evidence see (Singer and Lamm 2009). The link to freeriding has been built in a recent paper by Frans van Winden: On the Role of Empathy and Sympathy in Sharing, mimeo 2009. In case the independence assumption was violated, the same way as in a two step Heckman selection model, we would still be able to identify the model through the fact that the logit component is non-linear, while the truncated OLS part of the model is linear. 


\begin{tabular}{|l|l|l|l|}
\hline & Tobit & Logit 0 & Trunc OLS \\
\hline prison & .028 & -.071 & .030 \\
& $(.251)$ & $(.493)$ & $(.274)$ \\
\hline cons & .173 & -.571 & .357 \\
& $(<.001)$ & $(<.001)$ & $(<.001)$ \\
\hline $\mathrm{N}$ & 20,871 & 20,871 & 13,336 \\
\hline Pseudo $\mathrm{R}^{2}$ & 0 & 0 & \\
\hline
\end{tabular}

Table 1

Comparing Prisoners with All Data

p-values in parenthesis, all models with robust standard errors, clustered for studies

If we confine the sample to those participants whose male gender has been specified, of 1,073 participants non-prisoners contribute on average $22.81 \%$, while prisoners contribute $29.31 \%$. In this comparison, the Tobit and the Logit models establish a significant advantage of prisoners, while prisoners do not contribute significantly more than male non-prisoners, provided both make a positive contribution $(\mathrm{p}=.962)$.

One might object that our prison participants knew they were interacting with an anonymous inmate of the same prison. In the standard dictator experiment, student subjects know that they are matched with another anonymous member of the same subject pool. Subject pool size is rarely reported. The subject pool of our own lab in Bonn with some 3500 registered participants is probably rather on the large side. Nonetheless one might argue that our prison participants had the impression of interacting with a member of a considerably smaller group, and that this group, all being walled in, was tied together more densely than students of the same university. It might therefore seem more appropriate to compare our sample with dictators who interact with other members of a more tightly defined group. Other experimenters have tested students who attend a school preparing them for entering the Indian Muslim clergy (Ahmed 2008); members of small Honduran villages directly after they had been hit by Hurricane Mitch (Carter and Castillo 2005); or they used a pretest to classify social distance, and matched participants accordingly (Leider, Möbius et al. 2009; Branas-Garza, Cobo-Reyes et al. 2010).

Figure 2 shows that these results do indeed look similar. Again mean contributions are very close. Non-prisoners on average contribute $29.12 \%$ of their endowment, while prisoners contribute $29.31 \%$. Statistically, there is no significant difference in the Tobit and the Logit models. Only in the truncated OLS part of the hurdle models, prisoners significantly outperform nonprisoners, provided either of them is willing to give a positive amount. Hence we conclude that, at the least, prisoners are not less sociable and generous than non-prisoners, if not more generous. 




Figure 2

Comparing with Other Pre-Defined Groups

\begin{tabular}{|l|l|l|l|}
\hline & Tobit & Logit 0 & Trunc OLS \\
\hline prison & -.014 & .358 & $.058 * *$ \\
\hline cons & $.293 * * *$ & $-.9997 * * *$ & $.376 * * *$ \\
\hline $\mathrm{N}$ & 400 & 400 & 288 \\
\hline
\end{tabular}

Table 2

Comparing with Other Pre-Defined Groups: Statistics

This finding may also be read as a contribution to a dispute among criminologists that has a long history. For almost a century, criminology has been divided over the cause of crime. While some believe it to result from personality (Wilson and Herrnstein 1985), others attribute it to the specific context in which the would-be criminal happens to be. The first school has explained crime with feeblemindedness (Goddard 1912), emotional instability (Abrahamsen 1960), antisocial personality (Gough 1968) or a systematic lack of self-control (Gottfredson and Hirschi 1990; Hay and Forrest 2006). In the tradition of Talcott Parsons, such claims have been backed by the idea that crime results from imperfect socialisation into norm guided behaviour (Parsons and Shils 1951). Others have asserted they have identified somatic markers (Sheldon 1949; Lombroso, Gibson et al. 2006) or, most recently, activation patterns in the brain (Kiehl, Smith et al. 2004). In this perspective, criminals are expected to be different people. Crime is a pathology.

By contrast, rational choice theory explains crime, as any behaviour, by a reaction to the opportunity structure (Becker 1968; Piliavin, Gartner et al. 1986). It at most reverts to personality factors if all situational factors have been shown not to explain the data (a well-known example is Wilson and Abrahamse 1992). Albeit from a different starting point and in a more cautious way, life-course criminology makes a similar claim (Sampson and Laub 1993). In this perspective, criminals are not different people. They are not pathological (Cornish 1993). In principle, everybody could commit a crime, provided he meets the right (wrong) circumstances. 
We have tested prisoners, not criminals. We have only tested them for selfishness, not for other personality traits. But we can exclude that our participants differ from the rest of the population by being more selfish. Actually, we can even go further. Arguably, if selfishness induces crime, those convicted for crimes against property should give less in the dictator game, since crimes like theft, fraud or robbery are more directly related to selfishness than crimes like assault, robbery, manslaughter, rape, obstructing a police officer, which we have dummy coded as violent crimes; robbery is the only crime in both categories. The fact that a prisoner appears in both categories occasionally also results from the fact that he has been convicted of several crimes. We have only three prisoners who appertain to neither category ( 2 drug dealers and one person convicted for threat and libel). ${ }^{5}$

\begin{tabular}{|l|c|c|c|}
\hline & $\begin{array}{c}\text { property } \\
\text { no }\end{array}$ & $\begin{array}{c}\text { property } \\
\text { yes }\end{array}$ & total \\
\hline violence no & 3 & 11 & 14 \\
\hline violence yes & 21 & 23 & 44 \\
\hline total & 24 & 34 & 58 \\
\hline
\end{tabular}

Table 3

Crimes

Both in a Tobit model, and in a hurdle model, we do not establish a significant effect of having been convicted for a crime against property, on the willingness to give in the dictator game.

This result does, of course, not imply that personality is irrelevant for explaining crime. Yet we add to the growing literature that calls for explaining crime by the interaction of personality and (perceived) situation (see, e.g. Nagin and Paternoster 1993; Paternoster and Brame 1997; Wright, Caspi et al. 1999; Nagin and Paternoster 2000; Nagin and Pogarsky 2001; Wright, Caspi et al. 2001; Eggleston Doherty 2006; Ousey and Wilcox 2007).

\section{Effects of Criminal Law Intervention on Selfishness}

Criminal policy has become less optimistic about the educative effect of criminal sanctions. Sceptics assert that "nothing works" (Martinson 1974) or they point to a lesser openness in society for the idea of rehabilitation (Garland 2001). Yet others insist that criminal law is a tool for socialisation (Tonry 1999:1765; Lappi-Seppälä 2001), for the internalisation of socially desirable norms (Robinson and Darley 2003:981). It helps prevent the dissociation of society into peer groups with socially detrimental group norms (Kahan 1997:355 and $358 \mathrm{f}$.). It contributes to morality (Andenaes 1952:180; Cramton 1968; Tittle and Rowe 1973; Katyal 1997:2448; Tonry

5 Since this number is so small, we cannot interact both types of crime. This would technically make these 3 observations the reference category, and would lead to spurious results. We also cannot code the other way round. Then the reference category would be prisoners who have committed a violent crime against property, which is a sufficiently rich cell. Yet all three prisoners who fall in neither category have given nothing. Therefore in this model the interaction effect would be collinear. 
1999:1765), which is why it ultimately keeps at least a certain educative effect (Meares, Katyal et al. 2004:1183). Legislators continue to list "rehabilitation" among the purposes criminal punishment is meant to serve (for an overview see Cotton 2000), and field data has been used to test the viability of rehabilitation programmes (Lipsey and Cullen 2007). In an educative perspective, punishment serves an expressive function (Sunstein 1996; Kahan 1997:383; Katyal 1997:2446; Cooter 1998; Adler 2000) (for a summary of earlier thinking see Tonry 1999:1764). It conveys meaning (Lessig 1995; Katyal 1997:351). Society gives prominence to values about which it seriously cares. Punishment is a symbol for this (Hawkins 1969:555 f.).

Of course, choices in the dictator game are no direct measure of successful rehabilitation. As pointed out earlier, many non-prisoners give nothing. One could hardly claim that all of them need correctional intervention to turn them into acceptable citizens. One might even say that giving nothing just shows that a participant understands the opportunity structure. Yet not keeping everything presupposes the willingness to control impulses. It shows that a prisoner is able to overcome selfishness and, more basically even, that he has empathy for another person whose well-being depends on this prisoner's action. From a rehabilitation perspective, all of this is desirable. It therefore is meaningful to test whether the severity of the sanction, the time already spent in prison, and prison schooling explain how prisoners behave in the dictator game.

It turns out that neither sanction severity, measured by the duration of the senctence, nor time left to serve in prison significantly explain choices in the dictator game. Adding control variables does not substantially change the picture, which is why we do not report these regressions here. Instead we focus on the effect of schooling.

The Adelsheim prison does not content itself with the general effect of serving a prison sentence on prisoner attitudes. It proactively intervenes in the interest of preparing prisoners for a life without crime. To that end 43 of our 58 participants, or $74.14 \%$ of them, have been sent to prison school. Day per day those singled out for school are marked. In keeping with the German tradition, marks run from 1 (best) down to 6 (worst). Marks are an overall measure for assiduity and engagement, and for performance in class. Pupils only receive a mark if, on that day, schooling was offered for at least the whole morning. The benchmark prison wage is $10.87 € /$ day. If the mark is smaller than 3 , for each decimal point the prisoner receives a bonus of $2 \%$. So if the daily mark is 2.5 , this prisoner receives $\left(1+5^{*} .02\right)^{*} 10.87 €=11.957 €$. By the same token, for any decimal point above 3 , the daily prison income is reduced by $4 \%$. Empirically, the maximum income per month is $270 €$. On average prisoners make $180 €$. Some make nothing. Do these efforts increase prisoners' willingness to give in the dictator game?

If prisoners are not sent to school, this does not imply that schooling were particularly unlikely to be successful. Mainly those do not go to school who are trained as apprentices. Consequently, being singled out for school cannot be interpreted as a summary judgement about rehabilitation prospects. Yet schooling gives the prison a more powerful opportunity to rehabilitate prisoners. Comparing choices in the dictator game between those who are schooled and those who are not is one way of assessing whether the intervention has been successful. 
The Tobit model is inconclusive, Table 4. If one separately considers the decision to give anything, and the size of positive contributions, it turns out that being selected for schooling has a negative influence on the decision to contribute at all, but a positive influence on the size of the contribution. The longer the sentence a prisoner still has to serve, the less he is likely to make a positive contribution. Conversely, the closer they are to the end of their terms, the more they are likely not to keep everything. However, the size of the contribution shrinks, provided the prisoner does not keep everything. Most interestingly, in the truncated OLS model, the interaction effect is significant. It has opposite sign of the main effect of remaining time in prison, and it is stronger than the former. Consequently those who receive schooling not only are more likely to make a positive contribution. They even make higher contributions than their co-prisoners who do not go to school. This indicates that schooling does indeed have a beneficial effect on prisoner sociality.

\begin{tabular}{|l|l|l|l|}
\hline & Tobit & Logit 0 & Trunc OLS \\
\hline school & .552 & $-6.840^{*}$ & $9.131^{* *}$ \\
\hline violence & $3.802^{+}$ & $3.199^{* *}$ & $-6.081^{* * *}$ \\
\hline $\begin{array}{l}\text { remaining } \\
\text { time in prison }\end{array}$ & -.082 & $-.223^{* *}$ & $.150^{*}$ \\
\hline school*remaining & .063 & .136 & $-.272^{*}$ \\
\hline cons & .699 & $6.303^{*}$ & 2.775 \\
\hline $\mathrm{N}$ & 58 & 58 & 38 \\
\hline $\mathrm{p}$ model & .2478 & .0222 & $<.001$ \\
\hline
\end{tabular}

Table 4

Explaining Choices in Dictator Game with Schooling

${ }^{* \star *} p<.001,{ }^{* *} p<.01,{ }^{*} p<.05,{ }^{+} p<.1$, robust standard errors

For those 43 participants who receive schooling, we also have the daily marks. Means of these marks over all days of attendance range from 1.333 to 4.783 . The models of Table 5 demonstrate that, if ever their effect is significant, schooling marks have a negative influence. Given the German system of marks, this means that those who are worse at school give less in the dictator game. The effect however is visible only in the Tobit model and in the truncated OLS part of the hurdle models. Hence marks are unrelated with the decision to give anything, but they matter for the amount if a prisoner makes a contribution. There are two alternative interpretations of this result. Either there is a selection effect. Those who manage well at school are more sociable. Or they learn to be more generous through schooling.

\begin{tabular}{|l|l|l|l|}
\hline & Tobit & Logit & TruncOLS \\
\hline mark & $-1.974^{+}$ & -.341 & $-2.277^{* *}$ \\
\hline cons & $8.021^{*}$ & 1.528 & $10.998^{* * *}$ \\
\hline $\mathrm{N}$ & 43 & 43 & 26 \\
\hline $\mathrm{p}$ model & .0497 & .3853 & .0075 \\
\hline
\end{tabular}

Table 5

Explaining Choices in Dictator Game with School Marks

${ }^{* * *} p<.001,{ }^{* *} p<.01,{ }^{*} p<.05,{ }^{+} p<.1$, robust standard errors 
To discriminate between these two alternative interpretations, we exploit a further feature of our dataset. Separately for each participant, we count days, beginning with the first of 78 days of observation at school, and regress the daily mark on the number of the day. ${ }^{6}$ This exercise yields a positive coefficient for 32, and a negative coefficient for 26 participants. Again, given the marking convention, a positive coefficient means that marks deteriorate over time. Hence less than half of the prisoners who attended school improved their mark over time. We dummy code those who did not. Table 6 shows that the learning interpretation is correct. Those whose marks deteriorated over time are less generous in the dictator game (provided they do not keep all the money themselves).

\begin{tabular}{|l|l|l|l|}
\hline & Tobit & Logit & TruncOLS \\
\hline deterioration & -1.907 & -.261 & $-3.708^{*}$ \\
\hline violence & $5.148^{+}$ & $2.623^{* *}$ & $-6.664^{* * *}$ \\
\hline cons & -1.641 & $-1.414^{+}$ & $11.812^{* * *}$ \\
\hline $\mathrm{N}$ & 43 & 43 & 26 \\
\hline $\mathrm{p}$ model & .1648 & .0155 & .0003 \\
\hline AIC & 190.574 & 52.296 & 130.863 \\
\hline
\end{tabular}

\section{Table 6}

Explaining Choices in Dictator Game with Sign of School Marks

${ }^{* \star *} p<.001,{ }^{* *} p<.01,{ }^{*} p<.05,{ }^{+} p<.1$, robust standard errors

\section{Conclusions}

Not despite of the fact, but because the dictator game is radically simple, a one-shot game with 58 prisoners has cast new light on three criminological issues. In their majority, prisoners violate the selfishness assumption that underlies textbook rational choice theories of crime. Depending on analytic strategy, the willingness of prisoners to donate to an anonymous is either not statistically significant from non-prisoners, or prisoners are even more generous. This speaks against the idea that selfishness as a personality trait predicts crime. Finally, the dictator game helps measure the effect of special rehabilitation programmes. Controlling for type of crime, one establishes that prisoners who receive schooling are less likely to share, but if they do, they give considerably more. Better marks at school translate into giving more, provided they give at all. Using the development of marks over time, we show that this is not a selection effect, but the result of schooling: those who improve their marks over time give more.

Potentially, there are three objections against our approach. Is dictator game giving really an adequate measure for criminal propensity and rehabilitation? In a legal sense, the answer is obviously no. The rules of the game make it clear that it is perfectly legal for the dictator to keep the entire endowment. Yet 25 years of dictator game experimentation, with a special focus on population heterogeneity, have demonstrated two things: it is extremely rare for the mean given to be

6 OLS, robust standard errors, $\mathrm{N}=$ number of days this prisoner attended school during the period of observation. 
close to zero; populations differ widely, and systematically, with respect to their average willingness to give (for detail see Engel 2010). It therefore is meaningful to use dictator games as a measure of sociality. If a person is willing to donate in this game, this person is sensitive to the fact that, due to the arbitrary intervention of a randomisation device, the recipient is at her mercy. If this motivates the dictator to give up some of her endowment, she has to resist the temptation to keep everything, despite the fact that there is total anonymity, so that she knows she will never be held accountable. Sensitivity to the needs of others, to the injustice of the situation, and the ability to resist temptation are also preconditions for desisting from many crimes.

Strictly speaking, we have not tested criminals, but prisoners. For our third research question, this cannot pose a problem. We want to learn the effects of being sent to prison, and of special rehabilitation programmes, on prisoner sociality. Admittedly, for our first two research questions, prisoners are only a proxy. Yet if even prisoners violate the selfishness assumption of rational choice theory, this must hold a fortiori for those convicted for lesser crimes. The same argument in principle holds for pure personality theories of crime. To be on the safe side, we have compared prisoners to those non-prisoners who belong to a closely knit group. Even in that comparison, prisoners slightly outperform non-prisoners. We had no reason to doubt that participants trusted our safeguards of anonymity, so that fear for informal sanctions cannot explain giving either.

We have tested the willingness of prisoners to share their experimental endowment with other inmates of the same prison. Through the procedures for establishing participant-participant anonymity, we can exclude that giving has been motivated by the threat of sanctions. But we cannot exclude that giving originates in the solidarity among prisoners, and in local norms of prison inmates. One might therefore be hesitant to extrapolate too readily from our finding to behaviour after these prisoners have been released. In future work, it would be interesting to compare the dictator game in prisoners with the identical game played by non-incarcerated convicts. Yet it is remarkable that prisoners behave in more or less the same way as members of other close-knit groups, and that schooling makes them more generous. Both suggest that the effect does at least not exclusively result from prison subculture.

Laboratory experiments are helpful to establish full experimental control. One of course pays a price for the cleanness of the result. One has to strip the situation of all the contextual factors that might contribute to the fact that an individual starts a criminal career, or that he ends one. Therefore in and of itself evidence like ours will not suffice to support choices in criminal policy. Yet this paper demonstrates how lab experiments can fruitfully corroborate theoretical claims and field evidence on long-standing issues in criminology. 


\section{References}

Abrahamsen, David (1960). The Psychology of Crime. New York, Columbia University Press.

AdLeR, MATThew D. (2000). "Expressive Theories of Law. A Skeptical Overview." University of Pennsylvania Law Review 148: 1363-1501.

Ahmed, Ali M. (2008). Are Religious People More Prosocial? A Quasi-Experimental Study with Madrasah Pupils in a Rural Community in India http://ideas.repec.org/p/hhs/gunwpe/0330.html.

Andenaes, Johannes (1952). "General Prevention - Illusion or Reality?" Journal of Criminal Law and Criminology 43: 176-198.

Anderson, Clare and David L. Dickinson (2010). "Bargaining and Trust. The Effects of 36-h Total Sleep Deprivation on Socially Interactive Decisions." Journal of Sleep Research 19: $* * *$.

Andreoni, James (1990). "Impure Altruism and Donations to Public Goods. A Theory of Warm-glow Giving." Economic Journal 100: 464-477.

Andreoni, JAmes (1995). "Warm-Glow versus Cold-Prickle. The Effects of Positive and Negative Framing on Cooperation in Experiments." Quarterly Journal of Economics 110: 1-17.

Andreoni, James and John Miller (2002). "Giving According to GARP. An Experimental Test of the Consistency of Preferences for Altruism." Econometrica 70: 737-753.

Bardsley, Nicholas (2008). "Dictator Game Giving. Altruism or Artefact?" Experimental Economics 11: 122-133.

Barr, Abigail, Chris Wallace, Jean Ensminger, Joseph Henrich, Clark Barrett, AleXander Bolyanatz, Juan Camilo Cardenas, Michael Gurven, Edwins Gwako, Carolyn lesorogol, Frank Marlowe, Richard McElreath, David Tracer and JOHN ZIKER (2009). Homo Æqualis: A Cross-Society Experimental Analysis of Three Bargaining Games http://ssrn.com/abstract=1485862.

Becker, Gary Stanley (1968). "Crime and Punishment. An Economic Approach." Journal of Political Economy 76: 169-217.

Benenson, Joyce F., Joanna Pascoe and Nicola Radmore (2007). "Children's Altruistic Behavior in the Dictator Game." Evolution and Human Behavior 28: 168-175.

Bolton, Gary E. and Axel Ockenfels (2000). "ERC: A Theory of Equity, Reciprocity and Competition." American Economic Review 90: 166-193. 
Bosch-Domènech, Antoni, Rosemarie Nagel and Juan V. SÁncheZ-Andrés (2010). "Prosocial Capabilities in Alzheimer's Patients." Journal of Gerontology: Social Sciences 65: $* * *$.

Branas-Garza, Pablo, Ramón Cobo-Reyes, María Paz Espinosa, Natalia Jiménez, JAROMÍR KovÁRÍK and GiOvANNi PONTI (2010). "Altruism and Social Integration." Games and Economic Behavior $* * *$ : ***.

CAmerer, Colin F. (2003). Behavioral Game Theory. Experiments in Strategic Interaction. New York, NY, Sage u.a.

CARTer, Michael R. and Marco Castillo (2005). Morals, Markets and Mutual Insurance. Using Economic Experiments to Study Recovery from Hurricane Mitch. The Social Economics of Poverty. Christopher B. Barrett. New York, Routledge: 268-287.

Charness, Gary and Matthew Rabin (2002). "Understanding Social Preferences with Simple Tests." Quarterly Journal of Economics 117: 817-869.

COOTER, Robert (1998). "Expressive Law and Economics." Journal of Legal Studies 27: 585608.

CORNISH, DEREK B. (1993). Theories of Action in Criminology. Learning Theory and Rational Choice. Approaches. Routine Activity and Rational Choice. Advances in Criminological Theory, Vol 5. Ronald V. Clarke und Marcus Felson. New Brunswick: 351-382.

Cotton, Michele (2000). "Back with a Vengeance. The Resilience of Retribution as an Articulated Purpose of Criminal Punishment." American Criminal Law Review 37: 1313-1362.

CragG, JoHn G. (1971). "Some Statistical Models for Limited Dependent Variables with Application to the Demand for Durable Goods." Econometrica 39: 829-844.

Cramton, Roger C. (1968). "Driver Behavior and Legal Sanctions. A Study of Deterrence." Michigan Law Review 67: 421-454.

EgGleston Doherty, Elaine (2006). "Self-Control, Social Bonds, and Desistance. A Test of Life-Course Interdependence." Criminology 44: 807-833.

Eide, Erling, Paul H. Rubin and Joanna M. ShePherd (2006). Economics of Crime. Boston, Now Publishers.

Engel, Christoph (2010). Dictator Games. A Meta-Study http://ssrn.com/abstract=1568732.

Engelmann, Dirk and Martin Strobel (2004). "Inequality Aversion, Efficiency, and Maximin Preferences in Simple Distribution Experiments." American Economic Review 94: 857-869. 
FARrington, DAVID P. (2003). "A Short History of Randomized Experiments in Criminology. A Meager Feast." Evaluation Review 27: 218-227.

FARrington, David P. and BRANDON C. Welsh (2005). "Randomized Experiments in Criminology. What Have We Learned in the Last Two Decades?" Journal of Experimental Criminology 1: 9-38.

Farrington, David P. and Brandon C. Welsh (2006). "A Half Century of Randomized Experiments on Crime and Justice." Crime and Justice 34: 55-132.

Fehr, ERnst and Klaus M. SCHMIDT (1999). "A Theory of Fairness, Competition, and Cooperation." Quarterly Journal of Economics 114: 817-868.

Fershtman, Chaim and Uri Gneezy (2001). "Discrimination in a Segmented Society. An Experimental Approach." Quarterly Journal of Economics 116: 351-377.

FISCHBACHER, URS (2007). "z-Tree. Zurich Toolbox for Ready-made Economic Experiments." Experimental Economics 10: 171-178.

Forsythe, Robert, Joel L. Horowitz, N.E. Savin and Martin Sefton (1994). "Fairness in Simple Bargaining Experiments." Games and Economic Behavior 6: 347-369.

Garland, David (2001). The Culture of Control. Crime and Social Order in Contemporary Society. Chicago, University of Chicago Press.

Goddard, Henry Herbert (1912). The Kallikak Family. A Study in the Heredity of Feeblemindedness. New York, Macmillan.

Gottfredson, Michael R. and Travis Hirschi (1990). A General Theory of Crime. Stanford, Calif., Stanford University Press.

Gough, Harrison G. (1968). An Interpreter's Syllabus for the California Psychological Inventory. Advances in Psychological Assessment. Paul McReynolds. Palo Alto, Science and Behaviour Books: 111-133.

Gurven, Michael (2004). "Economic Games Among the Amazonian Tsimane. Exploring the Roles of Market Access, Costs of Giving, and Cooperation on Pro-Social Game Behavior." Experimental Economics 7: 5-24.

Gurven, Michael, Arianna Zanolini and Eric Schniter (2008). "Culture Sometimes Matters. Intra-cultural Variation in Pro-social Behavior Among Tsimane Amerindians." Journal of Economic Behavior \& Organization 67: 587-607.

Harbaugh, William T. and Kate Krause (2000). "Children's Altruism in Public Good and Dictator Experiments." Economic Inquiry 38: 95-109. 
Harbaugh, William T., Kate Krause and Steven G. Liday (2003). Bargaining by Children http://economics.uoregon.edu/papers/UO-2002-4_Harbaugh_Kid_Bargaining.pdf.

Hawkins, GoRdon (1969). "Punishment and Deterrence. The Educative, Moralizing, and Habituative Effects." Wisconsin Law Review: 550-565.

Hay, Carter and Walter Forrest (2006). "The Development of Self-Control. Examining Self-Control Theory's Stability Thesis." Criminology 44: 739-774.

Henrich, JosePh and Robert Boyd, Eds. (2004). Foundations of Human Sociality. Economic Experiments and Ethnographic Evidence from Fifteen Small-Scale Societies. Oxford, Oxford Univ. Press.

Henrich, Joseph and Robert Boyd (2005). "'Economic Man' in Cross-Cultural Perspective. Behavioral Experiments in 15 Small-Scale Societies." Behavioral and Brain Sciences 28: 795-815.

Hoffman, Elizabeth, Kevin McCabe, Keith Shachat and Vernon L. Smith (1994). "Preferences, Property Rights, and Anonymity in Experimental Games." Games and Economic Behavior 7: 346-380.

Hoffman, Elizabeth, Kevin McCabe and Vernon L. Smith (1996). "Social Distance and Other-Regarding Behavior in Dictator Games." American Economic Review 86: 653-660.

Holm, HaKan J. and Anders Danielson (2005). "Tropic Trust versus Nordic Trust. Experimental Evidence from Tanzania and Sweden." Economic Journal 115: 505-532.

Houser, DANIEl and DANIEl SchunK (2009). "Social Environments With Competitive Pressure: Gender Effects in the Decisions of German Schoolchildren." Journal of Economic Psychology 30: 634-641.

KAgEl, JoHn HenRY and Alvin E. Roth, Eds. (1995). The Handbook of Experimental Economics. Princeton, NJ, Princeton Univ. Press.

KAHAN, DAN (1997). "Social Influence, Social Meaning, and Deterrence." Virginia Law Review 83: 349-395.

Kahneman, Daniel, Jack L. Knetsch and Richard Thaler (1986). "Fairness and the Assumptions of Economics." Journal of Business 59: S285-S300.

Katyal, Neal (1997). "Deterrence's Difficulty." Michigan Law Review 95: 2385-2476.

Kiehl, Kent A., Andra M. Smith, Adrianna Mendrek, Bruce B. Forster, Robert D. Hare and Peter F. LiddLe (2004). "Temporal Lobe Abnormalities in Semantic Processing by Criminal Psychopaths as Revealed by Functional Magnetic Resonance Imaging." Psychiatry Research Neuroimaging 130: 297-312. 
LapPI-SEPPÄlä, TAPIO (2001). Sentencing and Punishment in Finland. The Decline of the Repressive Ideal. Sentencing and Sanctions in Western Countries. Michael Tonry. New York, Oxford Press: 92-150.

Leider, Stephen, Markus M. Möbius, Tanya Rosenblat and Quoc-Anh Do (2009). What Do We Expect from Our Friends?

https://mercury.smu.edu.sg/rsrchpubupload/15345/ExpectFriends.pdf.

Lessig, LAwrence (1995). "The Regulation of Social Meaning." University of Chicago Law Review 62: 943-1045.

LiPSEy, MARK W. and Francis T. CUllen (2007). "The Effectiveness of Correctional Rehabilitation. A Review of Systematic Reviews." Annual Review of Law and Social Science 3: 297-320.

List, JOHN A. (2007). "On the Interpretation of Giving in Dictator Games." Journal of Political Economy 115: 482-493.

Lombroso, Cesare, Mary Gibson and Nicole Hahn Rafter (2006). Criminal man. Durham, NC, Duke University Press.

Martinson, Robert (1974). "What Works? Questions and Answers about Prison Reform." Journal of Public Interest 36: 22-54.

MCDowell, Allen (2003). "From the Help Desk. Hurdle Models." Stata Journal 3: 178-184.

Meares, Tracey L., Neal Katyal and Dan Kahan (2004). "Updating the Study of Punishment." Stanford Law Review 56: 1171-1210.

Nagin, Daniel and Ray Paternoster (1993). "Enduring Individual Differences and Rational Choice Theories of Crime." Law and Society Review 27: 467-496.

Nagin, Daniel and Ray Paternoster (2000). "Population Heterogeneity and State Dependence. State of the Evidence and Directions for Future Research." Journal of Quantitative Criminology 16: 117-144.

NAgin, Daniel S. and Greg Pogarsky (2001). "Integrating Celerity, Impulsivity, and Extralegal Sanction Threats into a Model of General Deterrence. Theory and Evidence." Criminology 39: 865-891.

Nagin, Daniel S. and Greg Pogarsky (2003). "An Experimental Investigation of Deterrence. Cheating, Self-Serving Bias, and Impulsivity." Criminology 41: 167-193.

Ousey, Graham C. and Pamela Wilcox (2007). "The Interaction of Antisocial Propensity and Life-Course Varying Predictors of Delinquent Behavior. Differences by Method of Estimation and Implications for Theory." Criminology 45: 313-354. 
Parsons, Talcott and Edward Shils (1951). Values, Motives, and Systems of Action. Toward a General Theory of Action. Talcott Parsons und Edward Shils. Cambridge, Harvard University Press: 47-275.

Paternoster, Ray and Robert Brame (1997). "Multiple Routes to Delinquency? A Test of Developmental and General Theories of Crime." Criminology 35: 49-84.

Petrosino, Anthony, Paul Kiff and Julia Lavenberg (2006). "Randomized Field Experiments Published in the British Journal of Criminology, 1960-2004." Journal of Experimental Criminology 2: 99-111.

Petrosino, Anthony, Carolyn Turpin-Petrosino and John Buehler (2003). "Scared Straight and Other Juvenile Awareness Programs for Preventing Juvenile Delinquency. A Systematic Review of the Randomized Experimental Evidence." Annals of the American Academy of Political and Social Science 589(41-62).

Piliavin, Irving, Rosemary Gartner, Craig Thornton and Ross L. Matsueda (1986). "Crime, Deterrence, and Rational Choice." American Sociological Review 51: 101-119.

Plott, Charles R. and Vernon L. Smith (2008). Handbook of Experimental Economics Results. Amsterdam; Oxford, North Holland.

Robinson, Paul H. and John M. Darley (2003). "The Role of Deterrence in the Formulation of Criminal Rules. At Its Worst When Doings Its Best." Georgetown Law Journal 91: 9491002.

SAmPson, Robert J. and John H. LAub (1993). Crime in the Making. Pathways and Turning Points Through Life. Cambridge, Mass., Harvard University Press.

Sheldon, William Herbert (1949). Varieties of Delinquent Youth. An Introduction to Constitutional Psychiatry. New York,, Harper.

Singer, TANiA and Claus Lamm (2009). "The Social Neuroscience of Empathy." Annals of the New York Academy of Sciences 1156: 81-96.

Sunstein, CAss R. (1996). "On the Expressive Function of Law." University of Pennsylvania Law Review 144: 2021-2053.

Takezawa, Masanori, Michaela Gummerum and Monika Keller (2006). "A Stage for the Rational Tail of the Emotional Dog. Roles of Moral Reasoning in Group Decision Making." Journal of Economic Psychology 27: 117-139.

Tittle, Charles R. and Alan R. Rowe (1973). "Moral Appeal, Sanction Threat, and Deviance. An Experimental Test." Social Problems 20: 488-498. 
Tonry, Michael (1999). "Rethinking Unthinkable Punishment Policies in America." UCLA Law Review 46: 1751-1791.

VAN Der Merwe, Wilhelm Gerhard and Justine Burns (2008). "What's in a Name? Racial Identity and Altruism in Post-Apartheid South-Africa." South African Journal of Economics 76: 266-275.

Van Winden, Frans and Elliott Ash (2010). On the Behavioral Economics of Crime http://www.fee.uva.nl/creed/pdffiles/windenashcrime2010.pdf.

Wilson, James Q. and Allan Abrahamse (1992). "Does Crime Pay?" Justice Quarterly 9: 359377.

Wilson, JAMES Q. and Richard J. HerRnsteIn (1985). Crime and Human Nature. New York, Simon and Schuster.

Wright, Bradley R.E., Avishalom Caspi, Terrie E. Moffitt, Richard A. Miech and Phil A. SiLvA (1999). "Low Self-Control, Social Bonds and Crime. Social Causation, Social Selection, or Both?" Criminology 37: 479-514.

Wright, Bradley R.E., Avishalom Caspi, Terrie E. Moffitt and Phil A. Silva (2001). "The Effects of Social Ties on Crime Vary by Criminal Propensity. A Life-course Model of Interdependence." Criminology 39: 321-351. 


\section{Appendix: Instructions}

The computer will randomly assign the role of "giver" and "recipient" to half of you. The giver disposes of 10 talers. He can entirely keep them for himself, or he can divide them between himself and the recipient, as he pleases. The recipient only gets what the giver assigns him. Hence if the giver keeps the 10 talers for himself, the recipient gets nothing.

You will not be told which role the computer has assigned to you. Therefore we will only ask you how you want to behave in the role of the giver. The computer will only afterwards randomly define who is actually giver and receiver, and will randomly assign a recipient to each giver. You will not be told to whom you have been assigned, and can therefore decide in full anonymity. 


\section{Preprints 2010}

2010/26: Weinschenk P., Skill Formation under Incomplete Information

2010/25: Brilon S., Job Assignment with Multivariate Skills

2010/24: Lang M., Wambach A., The fog of fraud - mitigating fraud by strategic ambiguity

2010/23: Albanese G., Sorge M. M., The Role of the Judiciary in the Public Decision Making Process

2010/22: Bade S., Electoral Competition with Uncertainty Averse Parties

2010/21: Leifeld P., Haunss S., A Comparison between Political Claims Analysis and Discourse Network Analysis: The Case of Software Patents in the European Union

2010/20: Burhop C., Gelman S., Transaction costs, liquidity and expected returns at the Berlin Stock Exchange, 1892-1913

2010/19: Hellwig M., Finanzkrise und Reformbedarf [The Financial Crisis and Regulatory Reform]

2010/18: Bierbrauer F., Optimal Income Taxation and Public-Goods Provision with Preference and Productivity Shocks

2010/17: Weinschenk P., Entry and Incumbent Innovation

2010/16: Bierbrauer F., Boyer P. C., The Pareto-Frontier in a simple Mirrleesian model of income taxation

2010/15: Grechenig K., Sekyra M., No Derivative Shareholder Suits in Europe - A Model of Percentage Limits and Collusion

2010/14: Bierbrauer F., On the optimality of optimal income taxation

2010/13: Engel C., An Experimental Contribution to the Theory of Customary (International) Law

2010/12: Leifeld P., Schneider V., Institutional communication revisited: Preferences, opportunity structures and scientific expertise in policy networks

2010/11: Grechenig K., Nicklisch A., Thöni C., Punishment despite Reasonable Doubt - A Public Goods Experiment with Uncertainty over Contributions

2010/10: Petersen N., Braucht die Rechtswissenschaft eine empirische Wende?

forthcoming in: Der Staat.

2010/09: Bade S., Ambiguous Act Equilibria

2010/08: Lehmann S., Volckart O., The Political Economy of Agricultural Protection: Sweden 1887

2010/07: Engel C., Dictator Games: A Meta Study

2010/06: Engel C., Irlenbusch B., Turning the Lab into Jeremy Bentham's Panopticon. The Effect of Punishment on Offenders and Non-Offenders,

2010/05: Gropp R., Hakenes H., Schnabel I., Competition, Risk-Shifting, and Public Bail-out Policies

2010/04: Slemrod J., Traxler C., Optimal observability in a linear income tax

2010/03: Baumann, Florian; Friehe, Tim; Grechenig, Kristoffel: Switching Consumers and Product Liability: On the Optimality of Incomplete Strict Liability

2010/02: Bierbrauer F., Hellwig M., Public-Good Provision in a Large Economy

2010/01: Bierbrauer F., Incomplete contracts and excludable public goods 